\title{
The Man Who Became a Puppet and His Wife Who Became a Doll
}

\author{
Roberta Kalechofsky \\ Jews for Animal Rights
}

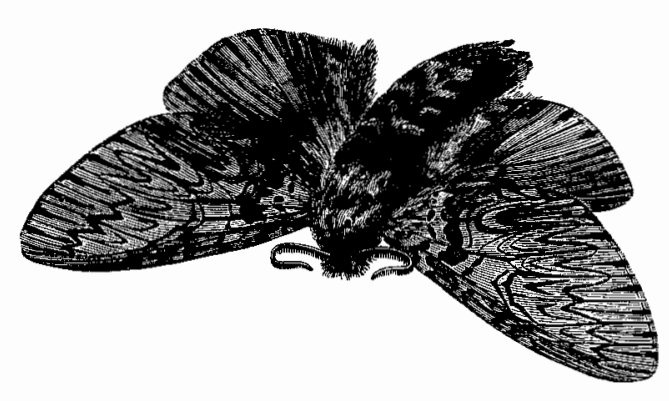

Behold, the Lord passed by and a great strong wind rent the mountains, and broke in pieces all the rocks, but the Lord's voice was not in the wind; and after the wind an earthquake came, but the Lord's voice was not in the fire, but in the silence. And when Elijah understood, he wrapped his face in his mantle.

His name, Oliver Galin Moore, was engraved in polished brass over the doorbell to his town house in London, and he walked up the front path to the doorway, a slender and decent looking young man of the Edwardian age. Married two years ago, he expressed the satisfied air of "coming into one's own," of someone whose marriage fulfilled him professionally.

His wife approached their house more critical of her domestic terrain, noting that the floral drapes on the bay window did not fall to her liking, and that the hedges along the brick path needed trimming, now that autumn was approaching. She was critical about such things, but this was precisely what he liked about her, feeling a security in her desire for perfection even when they conflicted about issues such as his basement laboratory. There would be no space for him at the

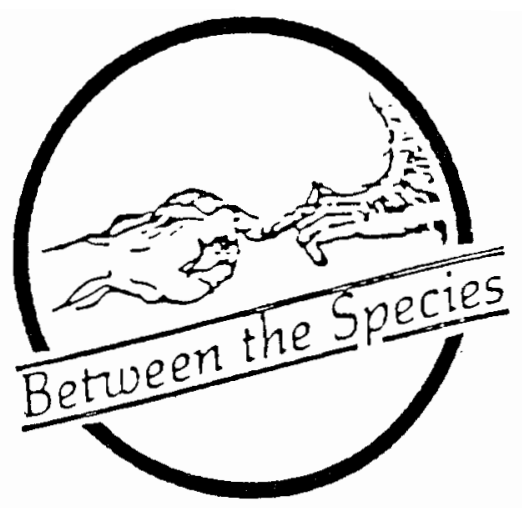

university for another year, and he was meticulous about solitude and preferred not to rent space in someone else's house. Both agreed that the laboratory would have a separate entrance on the side of the house so that there would be no interference between their place of residence and his workplace, between her space and his. He rigorously enforced this separation, and she accepted it as part of her duty that nothing would interfere with his work. In her mind's eye she saw his space as immaculate space, cluttered perhaps, but with a clean industrial disarray. She saw him at his work in the center of this space, with his eye cupped into his microscope like photographs she had seen of Pasteur, expressing a competency in reading the hieroglyphics of matter, though she never visited him in his laboratory. It was Dr. Moore's habit of writing into his notebooks that was familiar to her, for along with his umbrella his notebook was his constant paraphernalia. He carried it with him every where and often propped it up at night on his knees, in bed, to enter data as she drifted into sleep. His notebook was at the breakfast table in the morning and on the mail table in the afternoons. Sometimes he read to her from it and his confidence in her elated her.

But she was hardly subservient when it came to the public. It was she who protected him from visitors, wellwishers, curiosity-seekers and newspaper people, and hid the disparaging comments from him. There were

(C) Roberta Kalechofsky, 1991

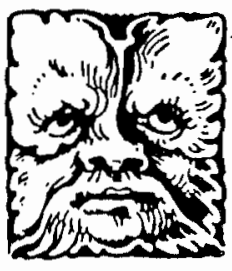


attacks upon him, some that might be described as vicious, but these were mainly in the Letters To The Editor columns, rarely in a science or medical journal.

\section{Dear Editor:}

"It is one thing to create a machine to look like and to imitate a human being, but quite another to make a human being imitate a machine. Dr. Moore's work is satanic and fiendish," etc., etc.

Yours, reverently, with Blessings Upon All Creatures, Mrs. Henry L. Lawton,

or signed The Reverend Thomas Smithy or Harriet Sellars, if the writer was an "emancipated" woman. The names might vary, but the style of the attackers remained the same.

His work had stirred unpleasant controversy. He was accused of creating "zombies whose souls had been sucked out of them," or if more eruditely written, "of sundering the boundary between life and inert matter." It had been demonstrated that curare could suspend the motor apparatus of an animal, while the autonomic functions of the body could operate normally, even separately. A frog had been rendered completely motionless, its breathing had been arrested, yet its heart had continued to breathe. Some people found this interesting, others thought it weird and wanted to know what the point was of discovering that you could paralyze someone, maintain his lungs with bellows while his heart beat by itself. Some wrote obscene letters, asking if the sex organs could function under curare, and what would be the purpose of that if a man couldn't put them to use. "Would this be heaven or hell?" Unpleasant ditties were sent to Dr. Moore and his wife. There had been a torchlight demonstration one night in front of their house, and a man threw a brick through the bay window with a note on it. "May you be cursed through all eternity." Oliver Moore quickly returned the brick, pinned his own note to it, "If so, I'll meet you in hell," opened the front door and threw it back. His action was applauded at his club the next day, though he was cautioned that had the brick maimed someone it would have claimed a martyr for the opposition. Professionally he was undemonstrative, but he had a temper when challenged by what he called hooligans and ignoramuses.

She, though as fragile as a Dresden doll, dealt much better with "the opposition," and shielded him from it as much as possible. When interviewed for an article, he called the public "ignorant rabble," and likened himself to Moses who tried to lead people out of their slavery, only to have them rebel against him and even threaten his life. She said more temperately, "People always fear the unknown."

The public might be apprehensive, but Mrs. Moore was charming. Moreover, she was informed about her husband's work: "Curare has distinct advantages over anesthesia because anesthesia tends to lower the body temperature and blood pressure in mammals, and has been observed even to reverse normal physiological responses. My husband's work has the commendation of the most reputable doctors and scientists. It is unassailable."

Photographs of them appeared in the social columns. He had thick brown hair, light brown eyes, a mustache and a goatee beard with a bit of red in it. She had wavy blonde hair fashioned stylishly on top of her head and the most amazing blue eyes, robin's egg blue, clear as crystal. She was diminutive, with an appropriate name, coming barely to his shoulder. Her fragility inspired confidence, and her ability to discuss her husband's research, though criticized by a few retrograde males, inspired awe in others. Though she held no view of his work other than "whatever will end the terrible sufferings of mankind must be fostered," she protected his vision and was accepted as a model of the wife of this new kind of professional man, forward-looking, whiggish, liberal yet reassuringly conservative about property, style, and decorum.

There was only one insoluble problem, and that was the odor that seeped from the laboratory upstairs into their rooms. It had started about half a year ago. When she first mentioned it to him he said he smelled nothing. But it continually gained in strength. Perhaps his sinuses were stuffed. She said she would have the building inspected. He dissuaded her, claiming the expense was unnecessary. The odor subsided for a while, but returned and became more powerful than ever, at least to her, defying ordinary efforts to dispel it. It was so unfamiliar, not at all like a strong cigar. She could not identify it, but it permeated everywhere, even upstairs into their bedroom, and permeated everything, including their bed linen. The time had come to get rid of it decisively, for she had reason to believe that she was pregnant. It would not do for the odor to penetrate the nursery.

For a while, her guests took the problem in good spirit-"Dr. Moore's chemical experiments"-and were 
delighted to get a whiff of the new odors symbolic of the future, until they became a bit more malodorous. Then her guests sat on her floral sofa with strained expressions, teacups untouched on their laps, the cookie tray untouched, their appetites diminished. The future was all very well and good if its odor did not seep into your food and rest on your tongue. "What causes it?" Mrs. Worthington-known for her "ungloved" mannerasked one day. "His experiments, I believe," Mrs. Moore said. "Ah!"Mrs. Worthington replied and dropped a sugar cube into her tea. "How long will it last?" she asked. Mrs. Moore generously moved the cake plate towards her guest. "Until the experiments are finished," she said. "Of course," Mrs. Worthington said, and looked thoughtfully at the cake tray, but declined.

Mrs. Moore felt determined to have the matter out once and for all. After her guest left, the fourth to leave abruptly in a fortmight, she flung a cape on her shoulders and went down the brick path to the laboratory. Buoyed by the realization that her guests were leaving her cake tray untouched, speaking sparsely and departing quickly-complaints she had registered for monthsshe knocked on the laboratory door, but he was not there. He had just left to fetch some equipment from the university laboratory, and in his haste had left the door unlocked. No one answered her knock. She imagined him lost in concentration and knocked again, louder. When he did not answer she felt mildly concerned that something had happened to him, he might have been overcome by the odor from his experiments. Beset by several excuses to see him immediately, including the impulse to disclose the news about her pregnancy, she tried the door, not expecting it to open, but it did.

The room was shrouded in shadows and felt surprisingly alien. It was empty and barren looking, more so than she had imagined, with only a worktable, her husband's notebook on it and an uncomfortablelooking stool, not even an armchair. A peculiar stillness hovered over the room, a silence like that of something behind a door, watching her. The sunlight flooded in behind her, a wicked glare of light beyond which rose ungainly shadows. She felt ill at ease, but unable to define the problem, she brushed past her feelings and picked up her husband's notebook which was endearingly familiar to her.

Rendered dog incapable of any movement, not even of breathing. Forced air into lungs through a machine. As Bernard observed--and
I observed myself - the dog knew everything that was going on, alert and suffering consciously. It could feel and know, but its motor apparatus was completely paralyzed and it could do nothing except suffer. One does experience a Pygmalian sensation at such power, nasty and thrilling. Must check.

Dissected out left side of the face, left side of neck, side of foreleg, interior of the belly and the hip. I lay bare the sciatic, the splanchneis, the median, the pneumo-gastric, the sympathetic and the infra-orbital nerves. No complaints from the dog, not even a howl. But it did urinate! I then excited the nerves with electricity for ten consecutive hours. Suppertime. Interrupted. Dolly always angry if kept waiting. Left electricity on all night. Returned in the morning to see effect, but dog had died. Must now obtain another dog

The reference to herself was disappointingly cool. She tried to understand it in the context of his being interrupted, a warning she took to heart now and turned to go. But a rustle in the room startled her. The sound was unnervingly loud in the unnatural silence, like a disembodied cough. Something moved in the dark against the wall. She peered hesitantly, though her instinct told her to retreat as quickly as possible. The shadows assembled themselves and became four cages stacked on top of each other. A dog, inspired by the unexpected light, crawled over a pile of torn newspaper, its hind legs moving disjointedly after him as if connected only by a thread to the rest of his body. A smell of blood and excrement rose in waves from its body as it moved. It made her nauseous and she wanted to leave. But where were her legs to carry her out? Other animals rose silently in the shadows. Their eyes fastened on her with motionless terror. The light from the doorway extended itself like a beam looking for its central object. At the end of the light, where it narrowed down to a splinter as sharp as the finger of God, a monkey lay rigid on the floor of a cage, his limbs stiff, his lips stretched across his teeth, his eyes beady and immobile, his body paralyzed except for a stream of saliva that foamed bitterly through his mouth. There was a hole in the side of its belly, with pipes and froth and blood bubbling out of it. She covered her face with her hands. Unreality assailed her, a sensation she had 
never experienced before or would ever be able to describe. Where were her legs to take her back into the real world? A part of her body had disappeared. The smell of blood and excrement attacked her in waves. Its familiarity appalled her. The wall of her belly gave way as if something were sliced from it. Blood overwhelmed her insides. It rose into her mouth. The wall of her belly crumbled like a piece of shale from the side of a cliff. Blood flooded her brain, a mucous red tide that bubbled into her eyes and mouth. She staggered out through the door.

Her husband found her minutes later, unconscious, at the bottom step to their house. "She must have tripped," he told Dr. Brodley, "banged her head on the step. A concussion. What do you think?"

"Perhaps," Dr. Brodley said, but his examination revealed the fact that she was pregnant. "A pleasant surprise," he smiled, to Dr. Moore's relief. "Light food, rest. She'll be all right. Ring me in the morning if there's a change."

He proved correct. Dolly Moore recovered to everyone's satisfaction, except that she became violent about her husband moving his laboratory elsewhere. The smells, she said, made her wretched. They made her guests wretched. They made her think, they stirred something in her brain, something that could not be remembered, that smothered her eyes with darkness if she tried. Dr. Moore did not need urging, for he believed that his laboratory had been broken into. Nothing had been taken, but his notebook had been knocked to the floor, the door was wide open, the animals were in a dither, his wife, he believed, had been struck when she had gone out to investigate noises there.

"Yes, that was it," she said.

He set up a new laboratory in a partially abandoned warehouse on the edge of London, which was preferable to anything within the city because it was obscure and would give him the solitude and protection from protesters and zealous students alike which he needed. Only his wife knew of the new location and wept with convulsive gratitude. "It's not for my sake. I don't want our child born into a house with such a smell."

Quixotically, the building was temporarily occupied by a group of circus performers, two clowns, two dwarfs, two jugglers, two tumblers, an animal tamer, a bareback rider, a fat lady, and a ventriloquist with a trunkful of puppets. They had taken refuge there for the winter, with an assortment of animals, a dog, a monkey, a horse, and a tame bearcub, but they would be leaving in the spring and had room to spare. It was November. The fields were beginning to freeze. For the most part he ignored them and they ignored him. They played cards and dice incessantly, cooked strongsmelling foods, shopped, visited, had visitors, and rehearsed their various skills: juggling, clowning, or tumbling. They were exactly the sort of people who would ensure his solitude and anonymity. Anonymous themselves, they practised a steely disregard, characteristic of itinerant groups whose rights in such circumstances are "squatter's rights."

But it was difficult to ignore the ventriloquist, a Mediterranean type, who was unabashedly intrusive and would even enter his laboratory without knocking, until Dr. Moore installed lock and bolt on both the inside and the outside. The ventriloquist's interest was touching but annoying. He had spent years in South America and knew about curare. "Did the doctor know how the Indians rendered their enemy dead, or to look like dead, more dead than Lazarus?" He crossed his hands over his chest in imitation of a corpse and lowered his eyes.

Though amused, Dr. Moore said, "It's not a theatrical prop."

"Of course not," the ventriloquist agreed quickly, "it is a medicine. But what do you say this is?" he asked, and produced a bark from one of Dr. Moore's dogs whose vocal cords had been cut.

Dr. Moore was startled, but recovered. His goatee beard caught a red tint from the bunsen burner, then jerked to a side at a precise angle. "I would say it's none of your business." The ventriloquist twirled his fingers in the air, a common gesture of his. "Of course," he said, and bowed in his characteristic stage manner.

He was a man of restless and acerbic intelligence, trained in a cunning discipline, with an imagination for its application that was boundless, and he had a sly sense of humor, sometimes also obscene. He could imitate accents, animal sounds, bird calls, steam hissing from a radiator, and even the crash of waves on rock so that he transformed a room into the ocean, and in the dark sometimes disoriented one. He was a master impersonator and woodcarver, with a trunkful of puppets which he used to satirize the age: Disraeli, Pasteur, Florence Nightingale, Napoleon, and others. But his talents, extraordinary as they were, were irrelevant to his society. Though anyone who had seen him perform found the experience unforgettable, he could barely make a living, and he nursed a deep, Iago- 
like grievance against the world, and sometimes took delight in being sinister. He hid in corridors and discombobulated people with unexpected sounds, a gun shot which brought everyone rushing out doors, a bird falling down from the ceiling with a shriek of death, the sound of smacking lips issuing from between the legs of the fat lady.

The others were tolerant and sometimes amused by him. For them, circus people, the world was a place of curious acts scraped together out of a bricolage of talents. They lived in an atmosphere of dog barks, bird calls, shrieks and hissing snakes, and the ventriloquist twirled his fingers at them as "unimportant rabble." After all, he knew more about curare than the doctor did. He had seen it used on human beings. Who else in England could say that? He was a world traveller and had spied out secret realities among unheard-of people and the pharmacopeia of jungles he had travelled through. From time to time he perched on top of the table in Dr. Moore's laboratory and told him about arcane medicines and poisons. Dr. Moore was annoyed at having his privacy invaded, but the ventriloquist could describe the effects of curare on human beings and this was invaluable.

There were three cages in his new laboratory, two dogs and a monkey. One of the dogs and the monkey were paralyzed and as inanimate as creatures in a taxidermist's studio. Their hair was stiff, their eyes were like marbles, their paws immobile. They lay on their backs like statues waiting to be packed into a box, the dog with her paws into the air like an upside down table, the monkey with an erection. The other dog scurried back and forth across her cage, scratching at places along the bars, looking for an opening while she tried, ludicrously, to bark at them without vocal cords. They were a strange pair in the laboratory: the ventriloquist with his nervously moving fingers, his rotting teeth and bad breath, and Dr. Moore's immaculate presence in his white smock, his silken goatee beard with a touch of red, and his light brown, steady, opaque eyes.

"Cojones," the ventriloquist smirked. "You would think otherwise, but it is the same with a man at the moment of death. The devil comes and strokes him." Dr. Moore ignored the comment. "What do you think," the ventriloquist urged, "do you think the monkey feels his cojones?" Whatever thoughts Dr. Moore had on this matter he was not going to share them with the ventriloquist who would translate them into his own obscene language.
"That question is not part of my experiment," Dr. Moore said, as he filled a hypodermic needle and prepared to inject curare into the other dog.

"But inside," the ventriloquist urged, "they feel everything. Is that not right?"

The question was cajoling and Dr. Moore ignored it. Moreover, he could not answer him. Pain is incoherent; the language of pain is primitive: a few grunts, groans, a grimace, a twitch. Claude Bernard had written that under curare, a victim might experience "the most atrocious suffering which the imagination of man can conceive," but this suffering has no discursive outlet. The logos inhabits the fields of love, theology, faith, knowledge, reason, but it has fled from the field of pain. Pain is the realm of unlove, un-faith, un-reason, un-knowledge. It has no color, no taste, no smell, gives rise to no images of the senses, has no developmental history, though we say that pain is a universal experience, that none shall escape it, that it has accompanied our history since human genesis. We are trapped in an elemental silence about our most profound experience. The language of love is eloquent, varied, whimsical, erotic, grotesque, sensual, imagistic, divine. But the language of pain is silence. It knows no metaphors. It is what it is, and in our noisy triumphalism of the word, we declare that this silence has no existence.

Dr. Moore plunged the needle into the soft haunch of the dog. "Possibly," was all he could rightly say, "but we can't be sure and if we can't be sure we shouldn't speculate."

"Ah, of course," the ventriloquist said, " but the Indians are sure. That's why they use curare. It is the power beyond death. They know how to make a man do their will even without curare, because they know what is on the inside. They know what is inside, no matter what is outside. I have seen a witch doctor cure a man of a deadly disease by putting the sound of a buzzing mosquito into his ear. At first the man twitched and slapped at his ear, but as the buzzing got louder and louder he threw off his blankets, jumped from his bed, slapped at his ear and ran about until he discovered that he was well."

"There was nothing wrong with the man," Dr. Moore said in a tone born from a weary contest with this argument. "Surely you don't believe that you can cure a sick man with a buzzing noise. Diseases are caused by real things, not by things in the mind or cured by buzzings in the ear." 
"Ah," the ventriloquist said, "of course, but can you make a well man sick with a buzzing noise?"

"Of course not," Dr. Moore said, as he lay down the rigid body of the dog who was afflicted with an impotent snarl in her immobilized jaw. "I do not waste time with these questions." He wished the ventriloquist gone, but it was difficult to get rid of him when one wished to. Even when he was not there physically, his personality was invasive.

But when he visited his wife on Sundays, he kept her amused with stories about the circus people, though sparingly mentioned the ventriloquist to her. "Talented man, but erratic. Brilliant but crude. Sad that he can't put his talents to better use."

Once he had stopped by the room which served them for a stage and watched them rehearse. The jugglers were surprisingly good, but depressed by their unfashionable talent. The clowns, the dwarfs, and the fat lady listlessly created a mock world. "It's all different when the real performance begins," the ventriloquist said. "On the real stage our talents sparkle. This is only a warehouse." He sat in the center of the empty room, a cigarillo dangling between his stained teeth, surrounded by his puppets carved to look like everyone one knew from the morning newspaper: Darwin, Pasteur, Disraeli, Queen Victoria, Gladstone, Huxley, Gordon and Cardinal Manning. The age spilled out of his trunk in a bunch of wooden heads, mutes with marble eyes and misbegotten contortions of their characters, Queen Victoria with Darwin's head, Darwin dressed like Florence Nightingale, history in drag, his sinister touch.

"Ah," he waved to Dr. Moore, "I am so glad to see you. Always. I have something for you. A gift."

Dr. Moore should have known better, but a gift is seductive. The ventriloquist took out of his trunk a blowgun ornately carved with lascivious animals, monkeys, boars, roosters, sexual organs poised with frenzy. Dr. Moore was embarrassed. The ventriloquist urged the gift on him. "You should take it. It is more useful than a hypodermic needle." "Thank you," Dr. Moore said stiffly, "but I believe not."

In between his visits, he wrote his wife laudable letters, urging that she take care of herself. She had gone to recover from her ailment to her cousin's house in Brighton, and sat all day on the boardwalk wrapped in blankets and stared at the sun, her focus shifting without motivation except with the instinct of the eye to adjust to changes in light. She looked serene, rose every morning, put on a tailored suit, ate a small breakfast, put a shawl on her shoulders, and went to the boardwalk. Her frame of reference was whatever was immediate: her clothes, her breakfast, her shawl, her accustomed place on the boardwalk.

She kept his letters, even cherished them, but never read them. She kept everything about him, the newspaper articles her cousin clipped and brought her, but she read nothing, having made an arrangement with the dark patch on her brain. Bizarre words in the articles attacked her: chloroform, anesthesia, mesmerism, pain, curare, germs, suspended animation, death-in-life, bright future. She had nothing to do with these words and bundled them away. When he visited her, she nodded in assent to everything he said. Their conversation was limited to the circus people. Since he had rigidly imposed a temporary isolation on his life, he knew little of what was happening in the world outside the warehouse except for what he read in the newspapers on Sundays when he took the train to Brighton. He worked twelve and fifteen hours a day, twelve and fifteen feverish hours, and sometimes well into the night, forgetting to eat his supper.

She observantly made mental notes about what living people did, how they spoke, how they nodded their heads, how they waved a hand, how a woman arranged her hatpin, and imitated them. Occasionally, unseen by others, a splinter of light pierced her brain and caused her anguish. Then she would gasp. If someone noticed, she laughed and said, "What a strong baby I will have. His kick almost threw me down." The shaft of light always arrived on a wave of voices, protesters, shouts, flaming torches. But she had learned how to defend herself against these. She clicked her eyes, once, twice, and the splinter of light was gone before it could stab her to death. It was a simple trick, but it always worked. She clicked her eyes open and shut, and the splinter of light was gone. Her serenity was disturbed only by these occasional struggles. Otherwise, the sky was remarkably clear, the ocean wonderfully blue. Small children chased a ball on the grass and a dog ran after them. His owner whistled, and the dog bounded back. If it ran with a splinter of light in its mouth, she clicked her eyes once, twice, and again, and wrapped her woolen shawl around her shoulders. She could not afford to become distracted. Waiting for her baby to be born took up all her attention.

Dr. Moore always returned from these visits to her eager to get back to work. The monkey lay supine, as he had left it in the morning, electrical wires plugged 
into its body, volts of electricity stimulating its nervous systems, its penis thrust into the air like a pink finger.

"Cojones," someone whispered one night. It was a sound like a cobweb across his ears, barely audible. He waved absentmindedly at it, bending over the monkey. A minute later the word was repeated more audibly, like a sigh in the canal of his ear. Athread of perspiration broke out over his lips. He stood up immediately and prepared to go to bed. He had been working too intensely without any of the normal distractions of other lecturers or meetings. He turned off the light and undressed in the dark. The electrical equipment attached to the monkey's nervous system hummed in the dark and focussed his attention.

"Cojones," someone whispered from under his bed, Dr. Moore sat up, his nerves alert. The room filled with animal sounds, sniffs, muffled snortings, wing flutterings, a wounded paw on a bed of leaves. A parrot called in the dark. Its blue wing flashed across his eyes. A snake slithered at the bottom of his bed. It raised its head and flicked its tongue at him. His nerves felt distended as if they had stretched out to the end of the world and he could hear every sound anywhere, the roaring ocean, the tinkle of bells, snow melting, a volcano rumbling, a couple groaning in love, the woman twittering with small gasps. Her noises came closer and closer. He could feel her body on top of him, smothering him with her beseeching groans to wrap his thighs around her body. His body filled with sexual urgency but grasped nothing.

Little by little the noises died away and he fell into a troubled sleep only to be awakened later by a buzzing in his ear, a small, cruel sound that seemed inside his brain. He slapped at it and it went away, but in the morning he was tired and irritable.

Nevertheless, the rest of the week was quiet. He worked normally, twelve, fifteen hours a day, dividing his time between his experiments and reading, and all but forgot what he now came to believe had been a nightmare. On Sunday he took the train to Brighton. It was now February. The air was still chilly, but there were a few feeble signs of spring. His wife, he noted, remained delightfully slender though she was now in her sixth month. When he bent down to kiss her goodbye, her eyes were as bright as ever, blue like chips of cerulean china.

But that Sunday night he was awakened again by noises in his room, slithering, sighing, scratching, nibbling, as if he were descending on to a forest floor.
He grasped the edges of his bed and forced himself to sit up, to stand up, to walk about, to turn on the light, to check his animals, to assert control, to check their heart beats, their blood pressures, the color of their tongues, the electrical equipment. The monkey's penis stuck into the air like the tip of a tongue. "Cojones," someone whispered and a lascivious flush, like the tail of a comet, trailed across his belly. His wife's eyes rolled out on the table, her glassy blue eyes stared up at him without invitation, her slender, upright body lay on the table like a doll. It was amazing how deluded he was. He had imagined she was alive, but she had deluded him. He was very angry with her for having deluded him. Someone knocked on his door. He turned off the lights and quietly, in the dark, found his way back to his cot and lay down on it. Within minutes, as he knew it would happen, there was a knock again. He made no sound. He knew it was the ventriloquist. He lay still for many minutes and finally heard footsteps going down the corridor. Little by little, silence and the dark brought him peace again. He must sleep. He knew that. He must sleep. In the morning he would make plans to move again. He would not, under any circumstances, stay here longer than it was necessary to find another place and move his equipment. He would choose his own battlefield and his own war.

In the morning, the ventriloquist greeted him in the hallway. "Dr. Moore! So unusual to see you leaving on a Monday."

"I have decided to look for a place closer to my wife. It is difficult for her that I am so far away."

"Of course," the ventriloquist smiled, "I wish you well." And in the evening when he returned the ventriloquist was there. "Have you found a place?"

Dr. Moore felt an impulse to lie. "Yes, I shall be moving next week."

"Permit me to help you."

"Thank you, but that won't be necessary. My colleagues, I'm sure, will assist me."

"That is wonderful. I wish you good luck."

"Yes, and good night," Dr. Moore said, and unlocked the door to his room. But it was no longer his room, though no one could have entered it and nothing had been touched. Everything felt strange to him, permeated by an inhospitable spirit. But he must bear with it until he could move. He could not leave in the middle of collecting data from his experiment. He must bear with it until he could find another suitable place. He was determined not to be forced to 
move precipitously, and put his white smock on and worked with intense concentration for several hours. He was determined to stay awake and work as long as he could, but eventually exhaustion overcame him and he lay down on his cot without undressing and, without surprise, an hour or two later was awakened by a buzzing in his ear. At first, he slapped at it, but immediately took hold of himself: it was useless to slap at something that was not there. He had to persist with self control. The buzzing subsided, and he slept for another hour when he was awakened again by another sound, the crackle of fire. The rotting boards in the warehouse were burning. He could smell the smoke. He leapt from his bed, unlocked his door and rushed out into the corridor, but there was no sign of fire here. The building was silent. There was nothing and no one. He turned to go back into his room when he felt a sting in the back of his neck, like the bite of an insect. He rubbed it impulsively, but his hand felt almost immediately strange. It tingled. His senses were at once alert, but his eyes became blurry, his legs became rubbery, and perspiration broke out on his forehead. He tried to move, but his body refused. It had become disconnected from his brain.

"Can I help you?" someone asked; and caught Dr. Moore as he was about to collapse. "Amazing," the ventriloquist said, "and so simple." He dragged Dr. Moore's body into his room and lay him down on his cot, careful not to disarray his smock. He wiped the perspiration from his forehead, and brushed his beard out with his fingers so that Dr. Moore should look like the self he was accustomed to being. "I assure you I wish only to do you honor," the ventriloquist said. Dr. Moore appeared on the verge of responding. His mouth was opened and his eyes were intense, but only a little foam gathered on his lips.

His wife sat on the boardwalk and waited for his next visit. After several weeks her cousin expressed surprise that Dr. Moore had not come but Mrs. Moore expressed nothing. She had all she could do to wait. It took up all her time. The ocean and the sky were wonderfully blue, the same color as her eyes.

\section{Monkeyman}

Monkeyman do what he wants

Daily dealing death for fun

Looking out for number one

In the monkey lab he haunts.

Unspeakables done to jews

Bashing brains, injecting strains

Of long slow death into the veins

Done to monkeys are no news.

Whitecoat doc do what he please

With the cousins in the cage;

I should be willing to wage

Monkeyman would break your knees.

Cretin king he's so pristine-

When there's kith and kin to slay,

Smartest monkey saves the day:

Misology a sorry scene.

Jerry Schwartz 